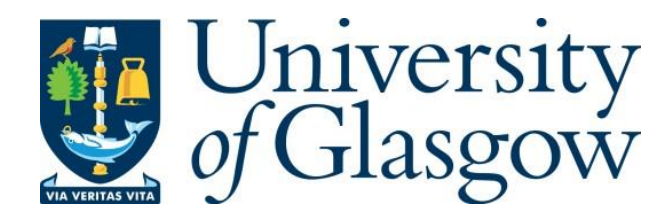

Hodge, S. and Parker, S. (2019) Social imaginaries in education research. In: Lynch, J., Rowlands, J., Gale, T. and Parker, S. (eds.) Practice Methodologies in Education Research. Routledge: Abingdon, Oxon ; New York, NY, pp. 144-165. ISBN 9780367193829.

There may be differences between this version and the published version. You are advised to consult the publisher's version if you wish to cite from it.

http://eprints.gla.ac.uk/183670/

Deposited on: 9 April 2019

Enlighten - Research publications by members of the University of Glasgow http://eprints.gla.ac.uk 


\section{Social imaginaries in education research}

\section{Steven Hodge (Griffith University) and Stephen Parker (University of Glasgow)}

The concept of social imaginaries is beginning to appear in education research, especially among critical researchers. In this literature, reference is consistently made to the work of Anderson, Castoriadis, Appadurai and Taylor. Among these thinkers, imaginaries are the shared yet tacit understandings about people, society and the world that are conveyed in a variety of ways including images, stories, sayings and popular ideas. Education researchers sometimes deploy the concept in investigations of interactions between policy and practice with a particular emphasis on what is taken to be the problematic spread and implementation of 'neoliberal' ideas in education practices. Comparison of the theory of social imaginaries with its appropriation in education research suggests that a number of researchers use the concept in a relatively limited and unjustifiably prescriptive way. In this chapter, we take the work of Charles Taylor as a reference point to examine this development of a methodology of imaginaries in critical education research. Taylor's account places imaginaries within the broader methodological notion of 'the background' which refers to a complex, layered cultural construction. A survey of Taylor's account of 'modernity' raises questions about the isolated use of the concept of social imaginaries seen in some education research and about the assumption social imaginaries can be the subject of intervention to bring about preferred educational futures. We argue that before the concept of social imaginaries can effectively inform methodologies for understanding and criticising education practices, researchers need to make more systematic use of the concept, in particular taking into account origins, background and tractability.

\section{Introduction}

The concept of social imaginaries, or simply imaginaries, is increasingly being taken up in education research (e.g., Rizvi \& Lingard 2010; Sellar 2013; Gale \& Hodge 2014; Yoon 2016; McKnight 2016). The attraction of the concept is that it offers researchers a way to identify and analyse widely shared, yet tacit, understandings about people, society and the world that are conveyed in a variety of ways including images, stories, sayings and popular ideas. Conceptually, imaginaries have been elaborated in the work of scholars in diverse fields, including Anderson, Castoriadis, Appadurai, Gaonkar, Taylor and others. Drawing on the contributions of these thinkers, education researchers have deployed the concept to make sense of the spread and adoption of problematic ideas in the practices of education, and the broader social contexts that shape them. The research of Charles Taylor is especially significant in some of this work partly because he assigns a special role to theory in the emergence and transformation of imaginaries, and partly because of his extended treatment of the topic (see in particular Taylor 2004 and 2007 ${ }^{1}$ ). As we have outlined elsewhere (Hodge \& Parker 2017) for Taylor, imaginaries can be partly determined by formal theories (such as those advanced by political theorists in scholarly contexts), which, through various processes, become translated and elaborated in images, stories and practices. Taylor's work consistently seeks to explicate 
larger structures that sit behind the specifics of everyday life. Although he does not provide definitions of these, his research distinguishes institutions and practices as basic characteristics of the social world (e.g., 2007, p. 1). Institutions may be regarded as stable, enduring structures endowed with materiality that may pattern our interactions and experience. The other is practices which are consistently advanced as more volatile patterns that structure our interactions and activities hour by hour. At other times, Taylor collapses the distinction between institutions and practices, subsuming both to social practices. For instance, speaking of a pervasive belief in God in Western societies a few centuries ago, he writes,

we see that God was present in the above sense in a whole host of social practices - not just the political - and at all levels of society: for instance, when the functioning mode of local government was the parish, and the parish was still primarily a community of prayer; or when guilds maintained a ritual life that was more than pro forma ... (Taylor 2007, p. 2).

In this quote 'social practices' is a broad category that appears to encompass all forms of social interaction and structure that constitute our everyday life. Importantly for our topic, Taylor sees these social practices as enabled by and made intelligible in imaginaries. Thus, the mutation and transformation of theories, imaginaries and practices go hand in hand.

The concept of social imaginaries is promising for education research. Numerous researchers have in the past wrestled with the problem of the apparent deformation of socially just educational practices by interests pursuing economic progress and rationality (e.g., Connell 2013), administrative efficiency (e.g., Bates 2006), or standardisation of outcomes (e.g., Lingard 2010). Problematic influences of these kinds are legion, and various theoretical approaches have emerged to account for their inroads into education (e.g., Marxian, Foucauldian, Bernsteinian, Bourdieusean). 'Social imaginaries' is a recent recruit to this critical project. The social imaginary offers a way to make sense of the diffusion of problematic ideas and the commitment people have to them that is not necessarily based on the theoretical coherence of arguments, but rather on the appeal of images, stories, sayings and popular ideas that translate and embroider the ideas. It is in the forms of the imaginary that people make these ideas their own, and participate in practices that are seen to reflect, embody and validate them. Social imaginaries thus present a methodology for comprehending participation in education, helping to account for the otherwise puzzling acquiescence of large numbers of people in problematic policies and practices. Taking on this account, critical education researchers have found that, for example, the ideas of 'neoliberal' economic and administrative theory have infiltrated educational practices and the imaginary associated with these. The argument goes that to change the practices, the related imaginary must change (e.g., Rizvi \& Lingard 2010). The challenge for these researchers becomes how to intervene in imaginaries to bring about more desirable educational futures.

In this chapter we set these assumptions and arguments in the context of Taylor's examination of modernity. We present the 'methodology' of that examination along with the picture of contemporary society that results. Hermeneutics and phenomenology combine in a unique way in this approach. The idea of 'the background' emerges as an important device in Taylor's works that includes imaginaries and a moral 'order' in a complex, layered and shifting 
construction that enables and makes sense of our participation in social practices. We then consider some examples of critical education research that use the idea of imaginaries to understand problematic practices and conceptualise interventions. Against Taylor's picture of modernity, this research can be understood as overlooking components of the background that may be useful to the critical project. This research also elaborates agendas that assume imaginaries are a viable target for intervention. We question this strategy in the light of the argued autonomy of imaginaries from theories, and of the necessary implication of agendas for change in the ramification of moral orders. In other words, we challenge the prescriptive use of imaginaries in some of the critical education research. We argue that before the concept of social imaginaries can effectively inform methodologies for understanding and criticising education practices, researchers need to make more systematic use of the concept, in particular taking into account origins, background and tractability. In mounting this argument, we will first provide an in-depth account of the social imaginary and its constituent elements.

\section{Keeping the background in view}

Taylor's methodological approach rests on the idea that everything we do-from the most simple, everyday act through to creating art, technology or theories - assumes a whole network of understandings that makes our doings intelligible to ourselves and others. Taylor refers to this network of assumptions as the 'background' in a number of his studies (e.g., Taylor 1993, 2002, 2004, 2007). He attributes the basic idea to $20^{\text {th }}$ Century philosophers Heidegger, Wittgenstein and Merleau-Ponty (Taylor 1993), and defines it as:

... that largely unstructured and inarticulate understanding of our whole situation, within which particular features of our world show up for us in the sense they have. It can never be adequately expressed in the form of explicit doctrines, because of its very unlimited and indefinite nature. (Taylor 2007, p. 17)

The background is an essential aspect in Taylor's work, and he contrasts it with the 'rationalist' tradition of social inquiry. Rationalism in part relies on positivist assumptions regarding the most appropriate procedures and methods to investigate the natural and social worlds. These often positivist modes of inquiry involve an atomisation of subjects into their constituent parts. More importantly, rationalism is founded on the view that the method reflects the way minds work, that is, by basic, atomic bits of information entering them and making more complex experiences. In Taylor's language, this process of reification is called 'ontologising', or 'the reading of the ideal method into the very constitution of the mind' (1993, p. 321). According to Taylor,

... this reification has been immensely influential, conferring on the resulting model of the mind all the prestige and unchallengeable force that the procedures of reason have acquired in our civilization. The more we learn to treat things rationalistically, the more we are inclined to accept the corresponding view of how we "really" operate. (1993, p. 321)

Theories of the human and social that assume some form of rationalism - such as behaviourism and cognitive psychology ${ }^{2}$ - thus treat the person as isolated or disengaged, entering into social 
relations as ontologically primary units, and view phenomena such as learning as the private acquisition of information from the environment without regard for social context. Much of Taylor's work is an attempt to account for this ontologizing shift and for the influence, prestige and force such ideas can have for common sense understandings.

Against this rationalist, atomistic account of the human, Taylor counterposes a socialhermeneutic view, arguing that humans are self-interpreting beings that understand themselves in the context of social practices (Taylor 1985; Gaonkar 2002). Rather than the material of thought and action being consciously filtered objective information about the world, the socialhermeneutic view is that understandings of activities and identity circulating in society are the basis of what we make of ourselves and our practices. Crucial to this perspective of human being is that the contents of understanding are not atomic, objective building blocks on which we deliberate and choose courses of action, but complex understandings available to us in virtue of our participation in the practices of society.

The social-hermeneutic view implies that humans are ontologically underdetermined, with their very substance being ultimately shaped by the repertoire of ways of being that circulate in our societies. On this view, to study and understand the human it is necessary to study and understand the repertoire of self-understandings. This is where the notion of 'the background' emerges as a fundamental methodological focus. Taylor argues that the reason the rationalist project is impossible is that all such theories seek to repudiate or step outside the background repertoire of human self-understanding. He explains that:

... the context that will give its sense to any theoretical account of human life we are entertaining will be the whole, tacit, background of what it is to be a human being. But this is so wide and deep that there can be no question of simply suspending it, and operating outside it. To suspend it altogether would be to understand nothing about human beings at all. (Taylor 2002a, p. 131)

Taylor's own studies can thus be regarded as the attempt to engage with this 'background of what it is to be a human being' as the only adequate approach to social inquiry.

Although Taylor does not articulate his mode of inquiry in the language of contemporary research methods, he does on occasion position his general approach as 'phenomenological' (e.g., 2007, pp. 307, 609). That is, he aims to discern meanings and structures of the background through systematic descriptions of human self-understandings. This approach involves detailing the repertoire upon which humans draw to illuminate and enable their participation in practices. Further, Taylor's methodology is characterised by a historical dimension that highlights how '[o]ur past is sedimented in our present' (2007, p. 29). From a methodological perspective, Taylor differentiates various levels or foci of the background that can be distinguished analytically but are intertwined empirically: social imaginaries, and what he calls a 'moral order'. A social imaginary is implicated in our understanding and thinking about practices but also in how we sense the way a practice ought to go and how people should act toward each other (2007, pp. 171-176). The background sits behind and is also exemplified in a social imaginary. The background also possesses a moral dimension: 
... an important part of this wider background is what I have called a sense of moral order. I mean by this more than just a grasp on the norms underlying our social practice, which are part of the immediate understanding which makes this practice possible. (Taylor 2007, p. 175)

Taylor characterises the moral aspect of the background to modernity as the modern moral order (2007, pp. 159-171), a general and diffused sense of how we ought to behave toward each other in contemporary society.

Taylor's methodology of the background is evident in many of his works, although the element of social imaginaries comes into focus especially in a series of studies that culminate in $A$ Secular Age (2007). This book conveys something of the complexity and layered nature of contemporary Western cultures and mobilises the methodology just sketched. A key concern of the book (and of Taylor's other work more general) is to account for 'modernity' and the increasing secularisation of western societies. The question that animates this work is 'why is it so hard to believe in God in (many milieux of) the modern West, while in 1500 it was virtually impossible not to?' (2007, p. 540). Taylor traces the shift from pre-modern times, through the Enlightenment to the contemporary era. Briefly, the pre-modern era was one when humans were surrounded by spirits and ghosts, assumed the efficacy of charms and potions, believed in separate and sacred times and places, and accepted their place in a stratified society that reflected the divine plan. But with the Enlightenment, the advent of science and scientific methods, and the apparent maturity of human reason, the mists of the pre-modern world were dispelled, and humans apparently now see things as they really are. Associated with this modern outlook, Taylor argues, are taken for granted notions of human rights and dignity, individual identity, democracy and freedom. ${ }^{3}$

Yet Taylor takes issue with this 'subtraction theory' of modernity, in which the traditions and world views that are seen to have blinded pre-moderns to their 'true' nature are thought to have fallen away through science and rationality. For Taylor, the subtraction theory of secularity does away with the background. Against this objectifying 'view from nowhere' stance, Taylor offers a systematic account of the construction of modernity and is at pains to illustrate the importance of the background - and with it social imaginaries - in shaping and underpinning human practices in modernity. We now draw out Taylor's argument here by examining the concepts of imaginaries and the moral order in more detail, in the process indicating how practices and theory enter into the construction of modernity.

\section{Modern social imaginaries}

Taylor's account of the background is fundamentally tied to his understanding of 'social imaginaries' (Hodge \& Parker, 2017; Gaonkar, 2002). Part of what makes social imaginaries distinctive is that it clearly separates formal theory from the way people generally understand themselves and their practices. As mentioned above, Taylor gives a special place to formal theory in the construction of the background, although not in the sense of providing a higher or prior rational foundation but rather as articulations that happen to resonate with prior moral and imaginary constructions (2007, pp. 175-176; Hodge \& Parker, 2017). Elites engage in the 
practice of theory making and from time to time produce articulations that resonate with shifts in imaginaries, practices and/or the moral order.

Social imaginaries also shape the intelligibility of practices. This intelligibility is articulated through images, legends, proverbs but also in the shape of theories. Imaginaries, moral orders, practices, and theories are always mutations or transformations of what has gone before. Hence to understand the present calls for a thoroughly historical awareness of its content. This principle is more than an ontological proposition: it has a methodological advantage insofar as detection of a change in the background helps to make visible the emergence of its historically specific social phenomena. Taylor's studies are chronicles of changing imaginaries and practices through whose vicissitudes can be discerned the depth and efficacy of the background, the slower-changing element of the moral order.

The 'imaginary' is a generative focus for inquiry because it refers to 'the way ordinary people "imagine" their social surroundings, and this is often not expressed in theoretical terms, it is carried in images, stories, legends, etc.' (2007, pp. 171-2). Again, 'theory' is often the possession of small, elite minorities (e.g., academics in the modern age, or revered thinkers such as Locke in previous eras), 'whereas what is interesting in the social imaginary is that it is shared by large groups of people, if not the whole of society' (p. 172). Taylor goes on to connect the concept of social imaginaries with the background. He says,

What I'm calling the social imaginary extends beyond the immediate background understanding that makes sense of our particular practices. This is not an arbitrary extension of the concept, because just as the practice without the understanding wouldn't make sense for us, and thus wouldn't be possible, so this understanding supposes, if it is to make sense, a wider grasp of our whole predicament, how we stand to each other, how we got to where we are, how we relate to other groups, etc. ... This wider grasp has no clear limits. That's the very nature of ... the "background". (Taylor 2007, pp. 172-3; emphasis added)

Here we make a distinction between two notions of the social imaginary: those understandings necessary for a) participating in specific practices; and b) the wider sense of how things are and should go, within which practice-level understandings sit. Taylor sometimes uses the language of 'mutation' (e.g., 2007, chapter 4) to highlight these particular forms of the social imaginary, giving rise to multiple imaginaries that each pertain to groups of practices. In the following, we outline three major forms or mutations of the social imaginary identified by Taylor (2004, 2007).

The broad notion of social imaginary (sense b), above) has some formal features, as intimated above and discussed elsewhere (Hodge \& Parker 2017):

Our social imaginary at any given time is complex. It incorporates a sense of the normal expectations that we have of each other; the kind of common understanding which enables us to carry out the collective practices which make up our social life. This incorporates some sense of how things usually go, but this is interwoven with an idea of how they ought to go, of what mis-steps would invalidate the practice. (Taylor 2007, p. 172) 
This is the broad concept of the social imaginary, 'shared by large groups of people, if not the whole society' (p. 172) and which connects with 'a wider grasp of our whole predicament ...' (p. 173). (Taylor further characterises this imaginary as 'modern', the formation of which we will consider below.) Social imaginaries - in both senses we have distinguished - have a dual structure. There is, on the one hand, a moral element and on the other, a foundation of intelligibility. The latter may be supplied by, or promotes the formation of images, stories and legends, but also formal theories. In this way, imaginaries are 'enabling' to practice because they make them both intelligible and give us a sense of how certain practices ought to go.

Although the social imaginary is complex and slowly changing, underlying it and moving more slowly still is the moral order that has become fundamental to our modernity. In the modern era this order is characterised by the sense that society is a collection of individuals acting for mutual benefit. Taylor traces the historical emergence of the 'modern' social imaginary to both transformations in the 'moral order', and to the theorisation of this transformation by elite thinkers (such as $17^{\text {th }}$ Century political theorists Locke and Grotius). Taylor puts this transformation succinctly:

Grotius derives the normative order underlying political society from the nature of its constitutive members. Human beings are rational, social agents who are meant to collaborate in peace to their mutual benefit.

Starting from the seventeenth century, this idea has come more and more to dominate our political thinking, and the way we imagine our society. It starts off in Grotius' version as a theory of what political society is, that is, what it is in aid of, and how it comes to be. But any theory of this kind also offers inescapably an idea of moral order. It tells us something about how we ought to live together in society. (2007, p. 159)

Grotius' theorisation presented here, as Taylor shows, builds on ideas promulgated by many thinkers and at different times during preceding centuries. As Taylor has described (e.g., 1994, 2007) the moral order before the modern era was hierarchical, with the ideal of society being something designed and imposed by the will of a god, or something pre-written into the cosmos awaiting actualisation. In this pre-modern 'vertical' form, society made sense as stratified, with different castes or classes attending to certain functions in accordance with eternal principles. But through many centuries of religious rivalry and war, elites became interested in finding a basis for social order that was not beholden to confessional differences. The theorisations of Locke and Grotius appear toward the end of the religious wars in Europe $\left(16^{\text {th }}\right.$ and $17^{\text {th }}$ Centuries), pulling together a vision of society as 'horizontal', that is, consisting of equal individuals, bound by 'contract'-like commitments, who can contribute on the same level to the harmonious functioning of society.

In A Secular Age, Taylor presents detailed accounts of the reception of these ideas by elites, and the work of 'glossing' and 'schematising' that accompanies the dissemination of such theories (Hodge \& Parker, 2017). What he means is that, through the action of countless discussions, reformulations, pamphlets and books, educational, artistic and policy routes, the ideas become widespread. Importantly, these 'glosses' are widely available to explain the emergence of new practices and to transform the intelligibility of old practices persisting under 
new conditions. It is when ideas, articulating and consistent with the moral order, start to become entwined in practices that a new social imaginary is established, in the 'dense sphere of common practice' (p. 176). This is the process of schematisation through which practices may be structured in ways consistent with theories, which in turn 'penetrates and transforms the social imaginary' (Taylor 2007, p. 175; see also Hodge \& Parker 2017, p. 50). The new modern social imaginary, then, is this image of social order-i.e., of individuals associating for mutual benefit - articulated in ideas that became available to large numbers of people through their participation in new and transformed practices, practices that 'define the contours of their world and can eventually come to count as the taken-for-granted shape of things, too obvious to mention' (p. 176). These processes took many decades, even centuries, to emerge and are still ramifying into the 21 st century.

Taylor describes three major 'mutations' of the modern social imaginary, which in effect are different articulations of the underlying moral order, each representing 'a penetration or transformation of the social imaginary by the Grotian-Lockean theory of the moral order' (2007, p. 176). These mutations are the 'the economy', 'the public sphere' and 'the sovereign people'.

The most germane of these to our argument, 'the economy', was articulated by Locke as a way to understand society (Taylor 2007). He found in commercial practices a metaphor of peaceful, productive co-existence. In Locke's thinking, the functioning of an economy stands as evidence that humans are predisposed to acting as rational individuals for mutual benefit, a perspective that he elaborated in his theory of Natural Law (Taylor 2007, p. 126). Other theorists such as Adam Smith developed these concepts further, introducing the ideas of the 'market' and the 'invisible hand' as a mechanism of market self-regulation, reconciling and coordinating the diverse, self-interested activities of individuals. Taylor explains that this emerging view of the economy as central to the organisation of society gradually infiltrated the social imaginary and profoundly shaped the range of possible practices, organising principles, and modes of thought. For example:

[the] notion of an invisible hand defines a new "normal" order, one of mutual enrichment; and in some ways it can be treated as such, and is invoked by various neo-liberal boosters of "the market" in our day. But it is not an order of collective action; for the "market" is the negation of collective action. It requires, to operate properly, a certain pattern of interventions (keeping order, enforcing contracts, setting weights and measures, etc.), and (tirelessly stressed) non-interventions (get the government off our backs). (Taylor 2007, p. 183)

Taylor highlights that with this formulation of the economy, a dichotomy or 'bifocal' is introduced into the modern imaginary at the broad level (2004, pp. 77-80). What he means is that the economic mutation of the social imaginary introduces an 'objectivising' understanding of moral order, a lens that views human action as something determined by economic forces in contrast with the lens constituted by the other mutations that accord humans and groups agency. The benevolent action of markets to curb and reconcile individual interests is understood as something that goes on behind the back of these individuals. It is to treat the order of society as something objective that in turn is amenable to study and even intervention in naturalscientific terms. To understand and intervene in society demands that we step back from the 
action so we can discern the invisible structures facilitating our collective action for mutual benefit.

Briefly, the other two mutations in Taylor's account contrast with this objectivising tendency of the economy. Like the economic version, the other forms - the 'public sphere' and 'the sovereign people' - articulate the foundation of society as individuals associating for mutual benefit, but stress human agency in articulating and operationalising the moral order. The public sphere and democratic activity each prioritise the role of explicit discourse and argument in setting the direction of society. To understand and intervene in society demands engagement in public debate, arguing for reasons and securing agreement.

In summary, Taylor's phenomenology of modern social imaginaries presents a reconstruction of the background that is whitewashed by rationalist social inquiry. Taylor's modernity is a compound of moral order, a primary take on this order in the form of a widely held imaginary, along with a set of more definite imaginaries or 'mutations' that cohere around related practices. These imaginaries foster distinct ways of explaining the social to ourselves. The economic mutation invites an objectivising or 'scientific' account of society, while the public sphere and democratic action commit us to discussion and argument to clarify and plan. Taylor thus offers both a methodology for inquiring into the social and a detailed phenomenology of modernity. We take these as a reference point for an appraisal of selected education research.

\section{Imaginaries in education research}

Our argument is that critical education researchers who have appropriated the concept of social imaginaries have often done so without considering a phenomenology of the background such as we find in Taylor's work. While we welcome the use of concepts and theories from outside of the education field to promote more socially just outcomes, we have reservations if important enabling or clarifying elements are omitted to the detriment of robust analysis. In the following, we provide examples of education research that have employed a somewhat reductive methodology of imaginaries. Methodologically, this research has not systematically considered the modern moral order that Taylor argues is fundamental to understanding the reception of theories and formation of imaginaries. These works often make claims regarding the 'imaginary' without taking into account the role and phenomenological importance of the background and the moral order. Indeed, they barely even consider these at all, potentially resulting in a superficial and disjointed picture of the imaginaries circulating in contemporary society. Finally, the implications of the autonomy of imaginaries from their constitutive theories and/or theoretical interventions have not been taken into account in education research. The critical agendas elaborated by these researchers assume - erroneously, we argue - that imaginaries can and should be targeted for intervention by researchers, politicians or others.

A relatively small number of education scholars have employed the concept of social imaginaries (e.g., Gale \& Hodge, 2014; Perry, 2018) although not all invoke or make use of Taylor's specific account of imaginaries. ${ }^{4}$ However, Rizvi and Lingard's (2010) influential book on globalisation and education policy is perhaps the most useful and most extensive 
example. Unlike the majority of the works that invoke the 'imaginary', their study explicitly considers the concept of social imaginaries and sets it within an extended treatment of globalisation, neoliberalism and their interactions with education policy. They explain that in the past two decades neoliberal economics has come to have a deep influence on education policy and practice. This new approach, Rizvi and Lingard (2010, p.185) argue, 'replaces the older, more liberal humanist and social democratic constructions of education which were underpinned by education's multiple purposes'. They describe conditions that have 'led to an almost universal shift from social democratic to neoliberal orientations in thinking about educational purposes and governance ...' (p. 3).

As Rizvi and Lingard's investigation of this shift focuses upon education policy, the work of elites is in question, specifically, elected representatives and government officials responsible for formulating policy. The authors explain that policy actors are no longer bound by national policy arenas and that we are witnessing global flows of elites and their ideas across multiple jurisdictions. Rizvi and Lingard reject 'ideology' as the most appropriate way to understand this set of loosely connected ideas. They accept that at one level, debate about the merits of neoliberalism is 'ideological' with different sides championing theories that are not necessarily well-scrutinised. Rizvi and Lingard go further in their argument: they believe that the ideas of neoliberalism have become 'translated' and 'internalised' by people generally (not just elites). These ideas have thus become 'part of their world view, shaping the ways in which they think about their social relations' and translated into 'material practices steering our sense of possibilities and conceptions of the future' (Rizvi \& Lingard 2010, p. 33). At this point in their discussion Rizvi and Lingard invoke Taylor in their argument that globalised neoliberalism has become a 'social imaginary', using Taylor's definitions of them as:

... the ways in which people imagine their social existence, how they fit together with others, how things go on between them and their fellows, the expectations that are normally met, and the deeper normative notions and images that underlie these expectations. (2004, p. 23)

They go on to explain that:

Globalization has produced not only material economic shifts, but also a changing set of identities and belonging. It has done this, we argue, through the development of a social imaginary about how the world is becoming interconnected and interdependent, an imaginary that now guides and shapes people's sense of the options for organizing conduct. (Rizvi \& Lingard 2010, p. 34; emphasis added)

At this point we can ask, to what extent does Rizvi and Lingard's analysis mesh with Taylor's own claims about modern social imaginaries? Clearly, what these researchers are posing with their imaginary aligns with Taylor's economic mutation. This is evident in Rizvi and Lingard's claim, above, that the neoliberal imaginary 'now guides and shapes people's sense of the options for organizing conduct'. It also conveys the objectivising rationality of economics, the ideas of 'preference for the minimalist state, concerned to promote the instrumental values of competition, economic efficiency and choice, to deregulate and privatize state functions' (2010, p. 159). Rizvi and Lingard's analysis is thus arguably an elaboration and update on Taylor's. Their global imaginary also seems to overlap with Taylor's imaginary of the public sphere. The argument that transnational flows of elites and their ideas have accelerated the 
spread and uptake of neo-liberal theory among policy makers connects with and extends the communicative medium of the public sphere. Since Taylor's mutations of the modern imaginary overlap and coexist, it seems reasonable to find the imaginaries of the economy and public sphere facilitating each other in the ways described by Rizvi and Lingard.

But if we look at how the latter's analysis takes up other elements of the background postulated by Taylor, we find little said about the moral order that is expressed in imaginaries. Yet Rizvi and Lingard explicitly address the idea that policy is about the allocation of values, and formulate questions in relation to education such as: 'where are these values to be found? What might be their content? Whose values are to be privileged? How should they be justified?' (p. 71). The authors argue that a theoretically compelling position on these questions is not sufficient to inform policy making, for the latter is inevitably a process of negotiation among values. From Taylor's perspective a question here is whether policy makers really have the agency to allocate values freely. If we are talking about the formation of social imaginaries, a deep historical analysis of the values context of policy makers would seem to be warranted, for the moral background would precede any act of value allocation.

However, Rizvi and Lingard's (2010) analysis does in fact indicate the operation of a more encompassing pull on values allocation via policy making. In a sense, they recognise the economic imaginary along with its moral vision when they describe:

... an unmistakable global trend toward a convergence in thinking about educational values ... There is thus a global shift towards a neoliberal values orientation, manifested most clearly in privatization policies and in policies that assume the validity of market mechanisms to solve various problems and crises facing governments. In education policy discourses, this has involved a reorientation of values from a focus on democracy and equality to the values of efficiency and accountability, with a greater emphasis on human capital formation allegedly demanded by the new knowledge industries, and required by nation-states to participate and compete successfully in the global economy. (Rizvi \& Lingard 2010, p. 72)

At the same time as Rizvi and Lingard tacitly acknowledge an encompassing moral order, they evoke the dichotomy of Taylor's 'modern bifocal' when describing the shift from concerns with equality and democracy to efficiency and accountability evident in the new imaginary of education. From the perspective of Taylor's phenomenology of imaginaries, what is articulated here is a positioning of education against one or the other side of the modern bifocal. That is, education is seen to align at one time with the democratic and social imaginaries characterised by the conviction that people can and should debate and reach agreement about the direction of practices and institutions. At another time education is beholden to the contrasting economic imaginary distinctive for the assumption that people are (unwittingly) acting in accordance with the presumed benevolent forces of the market. To understand and facilitate this engine of social good calls for, in this case, investigation of the role of education in harmonising interests and the removal of obstacles discerned through such investigation to its market function. The problem with Rizvi and Lingard's analysis from the perspective of Taylor's bifocal is that it does not take into account that neoliberalism is but an elaboration of the economic mutation of the modern social imaginary. This means, if neoliberal principles indeed characterise contemporary education, it is captured by an imaginary that has been in place for centuries and 
has deep purchase on our moral sense. By this account, if education has been framed by the economic imaginary, large numbers of people will sense the framing to be fitting. As a mutation of the modern moral order, the economy has a fundamentally legitimate claim on our sense of how we should behave toward one another and to judge by the penetration of economic categories into every-day thinking it is a mutation that is accepted by large parts of the population.

An added attraction of the economic framing of education may be that the 'objectivising' action of the economic lens of the modern bifocal produces the sense that education can be legitimately conceptualised in instrumental terms. Now, it is clear that a 'scientific' angle or claim on education has been present at least since the early part of the $20^{\text {th }}$ Century, as we witness in the debates between Dewey and Thorndike (Tomlinson, 1997) for example. However, through those debates, the 'methodology wars' (Webb 2014, p. 364; Howe 2009) over education research have not been convincingly won by either side. It might seem legitimate that education should be a social-democratic institution, or that scientific, 'evidencebased' methods should reform education, with both sides influencing policy and practice during the last century. ${ }^{5}$ However, the emergence of an economic interpretation of education galvanises the modern moral order through mobilising the social imaginary and its mutations. The economic imaginary, already a deeply felt way of understanding and participating in certain practices, can come to be seen as a legitimate frame for education too. But when the prestige of scientific rationalism is added to the mix, we may be witnessing a new and potent alliance between moral appropriateness and objective science. If education is accepted as a set of practices that can be enabled and illuminated by the economic worldview, then a corollary would be that it is legitimate to determine education's proper functioning and associated obstacles 'scientifically'. Education would then be something we do not argue about, whose purposes are not up for debate, but rather something analysed dispassionately in terms of 'what works' and, ideally, released from the grip of ideas and practices that are thought to have rendered it dysfunctional (Biesta 2010). As Rizvi and Lingard (2010) are aware, economic theory has developed new tools (e.g., human capital theory) that promise to provide finegrained analysis, employing the seemingly rigorous and neutral techniques of the natural sciences to produce new understandings of how education can be more precisely manipulated to produce desired social outcomes such as prosperity. Linked with this are further neoliberal innovations such as public choice theory (Buchanan, 1999) that cast aspersions on the social democratic conviction that educators cannot be trusted to determine optimal outcomes from education. A possible alliance between the economic imaginary and scientism as applied to the sphere of education may be difficult to overcome because the 'master narrative' of modernity (Taylor 2007) - that through science we have overcome the childishness of a world of spirits and enchantment (see above) - is activated. Thus, we might be in a situation where, in the wake of the economic capture of education, a 'scientific' approach to education could seem an obvious, common-sense part of the maturity of modern humanity, decisively supplanting social-democratic claims.

This reading of the impact of layers of the background, including the moral order, social imaginaries and the narrative of modernity, suggests that a deliberate and decisive shift away 
from an economic imaginary of education would be difficult to chart and engineer. Taylor's 'modern bifocal' represents dichotomous options for understanding and acting upon society. From this perspective critical education research has been relatively narrow in its application. That is, the bare concept of imaginaries has been appropriated by Rizvi and Lingard (2010) without considering other elements of the background or the potential insights of the detailed phenomenology developed by Taylor. Part of this possible misuse extends from the superficial readings of Taylor. Tellingly, Rizvi and Lingard use Taylor's own (2004, p. 23) definition of the social imaginary ${ }^{6}$ to argue that:

... the idea of social imaginary is akin to Pierre Bourdieu's notion of 'habitus' (1986), or Raymond Williams's idea of 'structures of feeling' (1977). A social imaginary is a way of thinking shared in a society by ordinary people, the common understandings that make everyday practices possible, giving them sense and legitimacy. It is largely implicit, embedded in ideas and practices, carrying within it deeper normative notions and images, constitutive of a society. (Rizvi \& Lingard 2010, p. 34)

Both 'habitus' and the 'structure of feeling' are more familiar concepts to researchers in the social sciences and humanities, and rely on fairly well understood ideas about how societies are thought to work. However, the social imaginary, in Taylor's terms, is something more historically rooted and morally powerful, and less amenable to direct interventions and change over time. While 'habitus' and the 'structure of feeling' may reflect, or be consistent with the social imaginary, they do not in themselves constitute an imaginary.

The criticism that researchers have appropriated an isolated notion of imaginaries can be levelled at the work of Gale and Hodge (2014), who seek a 'just imaginary' in transformations to policy and practice in higher education. In Gale and Hodge's argument the concept of social imaginaries is not addressed in relation to a wider context nor, although they reference Taylor's work, do they consider the results of his own phenomenology of imaginaries. That is, there is no attempt to relate their analysis to purported phenomena of the moral order or to argue against its relevance even though the very idea of a 'just imaginary' is a value-laden notion that resonates with the modern moral order described by Taylor. ${ }^{7}$ Other uses of the concept of imaginaries in education research make little or no effort to explain or justify the term. For example, Yoon (2016) and McKnight (2016) each employ the notion of a neoliberal imaginary of education, but it remains unclear how it is understood in these papers. The concept of imaginaries is mobilised by itself without reference to any other constructions or processes of construction. In such critical education research, a narrow appropriation of the concept is evident.

Another question raised by Taylor's work is whether imaginaries can be the subject of intervention, critical or otherwise. Imaginaries have imponderably complex beginnings, with factors arising from prior imaginaries, shifting moral orders, glossing and schematisation of theories, creation and re-purposing of practices (see Hodge \& Parker 2017). Theories of imaginaries, such as Taylor's, foreground the dynamic and unstable nature of these constructions. To regard imaginaries as fluid like this seems to justify the view that they are tractable, that there must be opportunities and means to directly influence their form and content. Sellar (2013) presents examples of social actors adopting this approach to imaginaries. 
Citing the work of Castoriadis, Appadurai, Gaonkar and Taylor, Sellar considers the influence of marketers and policy makers on the emergence of social imaginaries. He agrees with Rizvi and Lingard and other critical researchers that a neoliberal imaginary has formed since the 1960s and 70s, but focuses on current influences, considering 'how marketers target the experiences of young people as sites through which to access and modulate social imaginaries' (2013, p. 35) and how policy-makers seek to stimulate aspiration for higher education. It should be noted that Sellar does not pass judgement on whether marketers and policy makers really can intervene in social imaginaries. Yet, as we have described above, social imaginaries have deep historical roots, and efforts to change, shape, or modulate them in the short term are likely to be futile. For their part Gale and Hodge (2014) use Ball's (1993) distinction between firstand second-order policy effects to suggest that second order effects can be identified with the emergence of an imaginary. Their argument thus assumes policy can foster certain imaginaries, although the point they make is that socially just policy can only be converted to a just imaginary if such policy interventions are sustained and consistent.

However, Rizvi and Lingard (2010) do argue that the neoliberal imaginary of education needs and can be changed for the better. They acknowledge that,

The transformation of a social imaginary is of course never easy to achieve, requiring a range of formal and informal strategies to shift the popular images that people associate with discourse and practices that are sometimes expressed explicitly, but mostly not. (Rizvi \& Lingard 2010, p. 34)

However, they seem convinced that such transformation is possible through a range of strategies. Their proposal is that an alternative and 'competing' imaginary needs to be formed. They explain that,

This competing and new imaginary will emphasize cosmopolitan learning that does not 'ontologize' market logic and the self-capitalizing individual, but seeks to work with a different moral sense of people's 'situatedness in the world', in ways that are both critical and reflexive. This imaginary would recognize the social and cultural nature of human behaviour and being, as well as concern for the collective common good within an environmentally sustainable politics. (Rizvi \& Lingard 2010, p. 201)

This counter-imaginary contains elements analogous to Taylor's imaginaries of the public sphere and democracy. That is, globalisation can be regarded as an extension of the imaginary of the public sphere, of an interconnected space of communication wherein debate can be imagined as transcending local, personalised communication. At the same time, the new imaginary of education that Rizvi and Lingard desire will return to social democratic principles that were sidelined by the neoliberal imaginary.

\section{Conclusion}

In these examples, critical education researchers assume social imaginaries are amenable to intervention and that the intentions of agents (including policy makers) can determine the content of imaginaries. In each of the examples, good reasons are adduced to reject the 
neoliberal framing of education in favour of a more social democratic version. Sellar's (2013) argument is more nuanced, presenting marketers as attempting to harness the neoliberal imaginary for the purpose of raising brand awareness and selling commodities although in Sellar's work, policy-makers act on imaginaries out of presumably socially just motives. Thus, these researchers agree that a social justice agenda can direct interventions in the imaginary.

However, as we have argued, Taylor's work suggests that there is reason to doubt that policy interventions can act on imaginaries in this way. A key reason here is that imaginaries are autonomous from the theorising of elites. Theories can become implicated in the formation of imaginaries as Taylor argues in his phenomenologies. As we have argued previously (Hodge \& Parker 2017), the influence of certain ideas and theories on shaping the imaginary is not simply by virtue of the cogence and coherence of those ideas. Rather, theories will attain dominance if they resonate with the slower-changing moral order, as Taylor (1985) has asserted with the case of rationalism and naturalism. ${ }^{8}$ It is more likely that the cynical efforts of marketers will be efficacious in some respects, but in that case the object is not to intervene to change but to elaborate and align with what is already in place. The goals of critical education researchers to overcome an economic imaginary of education cannot follow from sound theory alone. Indeed, part of the methodological attraction of the concept of imaginaries is that it helps us understand the resistance of practices to compelling theory. The point is that once an imaginary is formed it is free from any theories (competing or complementary) that might have been involved in their emergence. Imaginaries have a life independent of the claims of reason. This means critical researchers have a problem if their agenda is only theoretically sound or if their argument is that the existing imaginary is theoretically flawed. To reiterate, what is needed to shift an imaginary is a morally compelling image of society, and this only develops and evolves over centuries.

Rizvi and Lingard (2010) appear to acknowledge the autonomy of imaginaries, writing that,

... the neoliberal social imaginary remains intact in education policy ... What seems clear is that this neoliberal social imaginary continues to hold us captive, well after its key assumptions have been rejected and been seen to have precipitated the global economic crisis, which is having negative real economy effects worldwide, with consequences for public policy. (p. 197; emphasis added)

But from Taylor's perspective, showing that the existing imaginary has its origins in discredited theoretical foundations and has negative effects would never be sufficient to shift it (Hodge \& Parker 2017). These are just arguments, and they are arguments as well that critical researchers offer in favour of an alternative imaginary. At best there is evidence to support these arguments and they are theoretically compelling. But by themselves, as Taylor has been at pains to establish, arguments and theories alone do not influence social imaginaries.

In some education research that uses the concept of imaginaries, we thus see a paradoxical resurgence of the rationalism Taylor was at pains to expose and discredit. The shift in imaginaries advocated by Rizvi and Lingard, among others, relies on the assumption that rational thought and beliefs can lead directly to desired change. The problem here is that the concept of imaginaries is lifted from a more extensive analysis of the background without addressing questions about the relevance (or not) of the modern moral order that underpin 
imaginaries. By not taking a wider view of the background into account, the way a moral order may work with or against critical agendas is overlooked in the strategy.

If, however, the background is taken more fully into account — at least as it appears in Taylor's phenomenologies - critical education research might benefit from considering issues such as the challenge posed by a convergence of the economic reading of education with a sense that it is also a 'scientific' perspective on education. For critical researchers a focus of action might then be to interrogate scientific claims made by neoliberal theories. For example, does public choice theory really present a feasible, objective analysis of the interests of educators? Again, researchers might consider the way critical agendas align with the modern moral order. How do agendas connect with mutations of the modern social imaginary, especially those that enable the non-objectivising side of the modern bifocal? A more systematic development of a methodology of imaginaries may help to deepen the critique and construct agendas capable of working with and through the background.

\footnotetext{
${ }^{1}$ Although arguably, Taylor's social imaginaries work is part of a broader oeuvre that includes investigations of philosophical anthropology, the self, multiculturalism, and critiques of scientism

${ }^{2}$ See Taylor 1964 and 1985.

3 Taylor describes this 'enchanted' society and the historical move towards disenchantment, individuality, inwardness and authenticity at great length in A Secular Age, building on arguments that he developed in earlier works (e.g. 1989, 1991, 1994).

${ }^{4}$ Indeed, some works reference 'imaginaries' with no references at all to any theoretical framework-e.g. Ball, 2012; McKnight, 2016; Yoon, 2016; the latter drawing superficially on Rizvi and Lingard's account.

5 This 'battle' currently seems to be in favour of the 'scientific' in the US, UK and other Western societies. For example, in England randomised control trials (RCTs) are gaining ascendency as the preferred research methodology in education, including among the influential Education Endowment Fund (see Childs \& Menter 2018; Churches 2016).

${ }^{6}$ This basic definition is also deployed by Perry (2018), Gale \& Hodge (2014), Gale \& Parker (2015), among others. Notably, most of these authors go no further into Taylor's account of the imaginary, resulting in superficial understandings that are more akin to more familiar concepts in social science.

${ }^{7}$ One of the authors of the present chapter co-authored the piece being criticised here. The argument advanced now stems in part from reflection on the use made of social imaginaries in that earlier paper.

${ }^{8}$ Taylor (1985, p. 6) claims that naturalism's 'epistemological weaknesses are more than made up for by its moral appeal,' specifically because 'the natural science model, stands an attachment to a certain picture of the agent. This picture is deeply attractive to moderns, both flattering and inspiring (p. 4).
}

\section{References}

Ball, SJ 1993, 'What is policy? Texts, trajectories and toolboxes', Discourse: Studies in the Cultural Politics of Education, vol. 13, no. 2, pp. 10-17.

Ball, SJ 2012, Global Education Inc.: New policy networks and the neo-liberal imaginary, Routledge, London. 
Bates, R 2006, 'Educational administration and social justice', Education, Citizenship and Social Justice, vol. 1, no. 2, pp. 141-56.

Biesta, GJJ 2010, "Why “What Works" Still Won't Work: From Evidence-Based Education to Value-Based Education', Studies in Philosophy and Education, vol. 29, no. 5, pp. 491503.

Buchanan, JM 1999, 'Politics without romance: A sketch of positive public choice theory and its normative implications', in Collected works of James M. Buchanan. Vol. I, Liberty Fund, Indianapolis. pp. 45-59.

Childs, A \& Menter, I (eds) 2018, Mobilising Teacher Researchers: Challenging Educational Inequality, Routledge, London.

Churches, R. (2016). Closing the Gap: Test and Learn: Research Report. London: Department for Education/National College for Teaching and Leadership. Retrieved from, https://www.gov.uk/government/uploads/system/uploads/attachment data/file/495580/clo sing the gap test and learn full report.pdf

Connell, R 2013, 'The neoliberal cascade and education: an essay on the market agenda and its consequences', Critical Studies in Education, vol. 54, no. 2, pp. 99-112.

Gale, T \& Hodge, S 2014, 'Just imaginary: delimiting social inclusion in higher education', British Journal of Sociology of Education, vol. 35, no. 5, pp. 688-709.

Gale, T \& Parker, S 2015, 'To aspire: a systematic reflection on understanding aspirations in higher education', The Australian Educational Researcher, vol. 42, no. 2, pp. 139-153.

Gaonkar, DP 2002, 'Toward New Imaginaries: An Introduction', Public Culture, vol. 14, no. 1, pp. 1-19.

Hodge, S \& Parker, S 2017, 'Accounting for practice in an age of theory: Charles Taylor's theory of social imaginaries', in J Lynch, J Rowlands, T Gale \& A Skourdoumbis (eds), Practice Theory and Education: Diffractive readings in professional practice, Routledge, Abingdon, pp. 39-54.

Howe, KR 2009, 'Positivist Dogmas, Rhetoric, and the Education Science Question', Educational Researcher, vol. 38, no. 6, pp. 428-440.

Lingard, B 2010, 'Policy borrowing, policy learning: testing times in Australian schooling', Critical Studies in Education, vol. 51, no. 2, pp. 129-47.

McKnight, L 2016, 'Meet the phallic teacher: designing curriculum and identity in a neoliberal imaginary', The Australian Educational Researcher, vol. 43, no. 4, pp. 473-486.

Perry, M 2018, 'Unpacking the imaginary in literacies of globality', Discourse: Studies in the Cultural Politics of Education, pp. 1-13.

Rizvi, F \& Lingard, B 2010, Globalizing Education Policy, Routledge, Abingdon.

Sellar, S 2013, 'Hoping for the best in education: Globalisation, social imaginaries and young people', Social Alternatives, vol. 32, no. 2, pp. 31-38.

Taylor, C 1964, The Explanation of Behaviour, Routledge \& Kegan Paul.

Taylor, C 1985, Human Agency and Language: Philosophical Papers 1, Cambridge University Press, Cambridge.

Taylor, C 1989, Sources of the Self: The Making of Modern Identity, Cambridge University Press, Cambridge. 
Taylor, C 1991, The Ethics of Authenticity, Harvard University Press, Cambridge, Mass.

Taylor, C 1993, 'Engaged agency and background in Heidegger', in CB Guignon (ed.), The Cambridge Companion to Heidegger, Cambridge University Press, Cambridge, pp. $317-$ 336.

Taylor, C 1994, Multiculturalism: examining the politics of recognition, Princeton University Press, Princeton, N.J.

Taylor, C 2002a, 'Gadamer and the Human Sciences', in R Dostal (ed.), The Cambridge Companion to Gadamer, Cambridge University Press, Cambridge, pp. 126-144.

Taylor, C 2002b, 'Modern Social Imaginaries', Public Culture, vol. 14, no. 1, pp. 91-124.

Taylor, C 2004, Modern Social Imaginaries, Duke University Press, Durham.

Taylor, C 2007, A Secular Age, The Belknap Press of Harvard University Press, Cambridge, Mass. and London.

Tomlinson, S 1997, 'Edward Lee Thorndike and John Dewey on the Science of Education', Oxford Review of Education, vol. 23, no. 3, pp. 365-383.

Webb, PT 2014, 'Policy problematization', International Journal of Qualitative Studies in Education, vol. 27, no. 3, pp. 364-376.

Yoon, E-S 2016, "Neoliberal imaginary, school choice, and "new elites" in public secondary schools', Curriculum Inquiry, vol. 46, no. 4, pp. 369-387. 